\title{
A construct of the instrument for measuring junior high school mathematics teacher's self-efficacy
}

\author{
${ }^{* 1}$ Rachmadi Widdiharto; ${ }^{2}$ Badrun Kartowagiran; ${ }^{3}$ Sugiman \\ *Centre for the Development and Empowerment of Mathematics Teachers and Educational \\ Personnel (PPPPTK Matematika) of Yogyakarta \\ Jl. Kaliurang Km. 6, Sambisari, Condong Catur, Depok, Sleman 55281, Yogyakarta, Indonesia \\ *Email: rachmadiw@yahoo.com
}

Submitted: 06 April 2017 | Revised: 15 July 2017 | Accepted: 15 July 2017

\begin{abstract}
The aim of this study was to develop a construct of the instrument for junior high school mathematics teacher self-efficacy and its mapping in the Special Region of Yogyakarta. The population was 816 junior high mathematics teacher, and a sample of 274 teachers was selected through proportionate random sampling technique. The data were analyzed using Confirmatory Factor Analysis (CFA), using Lisrel 8.80 software through the first order and the second order stages. The result of data analysis toward four dimensions obtained: 11 fit items for dimension of personal efficacy (PE), 12 fit items for dimension of general teaching efficacy (GTE), 13 fit items for dimension of subject matter teaching efficacy (STE), and 8 fit items for dimension of outcome efficacy (OE). Afterward, the result of selecting 54 items in the first order stage was examined for the second order CFA, which shows the model is fit to the data and obtains 25 fit items. The loading factors for each dimension PE, GTE, STE, and OE consecutively were: 0.46; $0.84 ; 0.89$, and 0.92 , and the mapping of mathematics teacher self-efficacy level shows: $43.07 \%$ in low category, $55.47 \%$ in medium category, and $1.46 \%$ in the high category.
\end{abstract}

Keywords: self-efficacy, construct, mathematics, junior high school

\section{How to cite item:}

Widdiharto, R., Kartowagiran, B., \& Sugiman, S. (2017). A construct of the instrument for measuring junior high school mathematics teacher's self-efficacy. REiD (Research and Evaluation in Education), 3(1), 6476. doi:http://dx.doi.org/10.21831/reid.v3i1.13559

\section{Introduction}

Increasing and improving teacher quality is continually implemented by the government through the fulfillment of academic qualification of S-1/D-IV, teacher certification, block grant for the continuation of the study, the revitalization of Teachers Working Group (Kelompoke Kerja Guru/KKG) for elementary school teachers, Subject-matter Teacher Forum (Musyawarah Guru Mata Pelajaran /MGMP) for junior and senior high school teachers, and program BERMUTU (Better Education through Reformed Man- agement and Universal Teacher Upgrading) (Jalal et al., 2009, p. 124). However, the government's efforts still failed to give satisfactory results when the condition of teacher teaching practices do not support the ability of students in mathematics achievement.

The results of TIMSS (Trends in International Mathematics and Science Study) Video Study 2007 (Leung \& Ragatz, 2010, p. 33) states that most junior high school mathematics teachers in Indonesia use $76 \%$ of their time to the problem activity and $24 \%$ for non-problem, while in Japan, $82 \%$ for problem activiy and $18 \%$ for non-problem, and 
Hong Kong $85 \%$ of problem activity and $15 \%$ for non-problem activity.

The Report of Training Need Assessment and Recruitment (PPPPTK Matematika, 2007 , p. 46) of a sample of 268 teachers in 15 provinces showed approximately $61.78 \%$ of the teachers had difficulty learning mathematics associated with problem solving. In a further interview with the respondents, there was a tendency for them to avoid delivering learning materials considered difficult. In terms of having no choice and a must to deliver the stated material, they lacked confidence in their performance or in their teaching practice.

Sumardyono (2011, p. 244) in a study of math anxiety to 89 participants of mathematics teachers training in PPPPTK Matematika in 2010, from the District of Banjarmasin, South Kalimantan, showed that adapting Mathematics Anxiety Rating Scale (MARS), increased the level of anxiety gradually from the higher education in which teachers teach to the lower education. It means that the high school teacher had a low level of anxiety compared to the junior high school mathematics teachers or primary school teachers.

Meanwhile, preliminary research conducted by the researchers to 38 junior high school mathematics teachers in Java, who attended PPPPTK Matematika training activities in 2012, by adopting Teacher Efficacy Scale (TES) from Tschannen-Moran, Hoy, and Hoy (1998), reported that $13.16 \%$ of those with high-efficacy scale categories, and approximately $86.84 \%$ efficacy scale were in a medium category. The teachers were also tested with Mathematics Teacher's Efficacy Belief Instrument (MTEBI) developed by Enoch \& Smith (1997) which states that most (almost all) their mathematics belief is in the medium category, and no participant was in the low or high category.

Hastuti et al. (2009) mention that teacher certification improves the welfare and likely improves the teachers quality because they can concentrate more and become more motivated. However, he was not convinced by it because increasing the quality and performance is a matter of personal commitment. Sadtyadi and Kartowagiran, (2014, p. 291) mention that through the assessment done by the time the teacher is teaching, it is difficult to describe the actual performance of teachers, because they have a tendency to be better prepared, than when monitoring is not done, in the assessment of its performance.

Based on that condition in which the teacher competence is still not optimal, and they themselves lack of confidence in carrying out the tasks they are responsible for, it is a bit difficult to expect they will be able to teach the material to their students well. Pajares (1996, p. 544) refers to Bandura's opinion that defines self-efficacy as a belief about their ability to successfully perform certain tasks in certain situations. Self-efficacy is also defined as an assessment of the person's ability to organize and execute courses of actions required to complete a type of work that has been determined, primarily for mathematics teachers' duties associated with fostering students' mathematical power (Kastberg, D'Ambrosio, McDermot, \& Saada, 2005, p. 10).

\section{Self-Concept}

Burn (1984) states that self-concept is a composite image of what we think we are, what we think we can achieve, what we think others think of us, and what would we like to be. Most social psychologists, one of whom, Rokeach, (Burn, 1984, p. 52) agree that selfconcept as a set of self- attitudes that consist of four components appear to be embodied: (a) a belief, or knowledge or cognitive component, (b) an affective or emotional component, (c) an evaluation, and (d) a predisposition to respond. Attitude organizes a relatively enduring belief in the object or situation around as a person's tendency to respond in various ways that he or she likes. Thus the self-concept is more of a hypothetical construct. In other words, it is a concept or a useful way to predict the attitude or behavior of a person, but must be careful not to 'filter' or judge the constructs as a thought that exists in the real world.

\section{Self-efficacy}

Another concept related to the belief of an individual or representation of one's self is the self-efficacy. Bandura in Keller (2010, p. 146) mentions another concept related to the 
belief in personal agency, i.e self-efficacy, the belief which is typically referred to as a person's belief that he or she can succeed in performing a given task. In line with this definition, Bandura also mentions self-efficacy as people's judgments on reviews of their abilities to organize and execute courses of action required to attain designated types of performances. Based on those opinions, it might be concluded that self-efficacy is defined as a belief or judgment about a person's ability to organize and execute courses of action required to complete a type of work that has been determined.

Keller (2010, p. 146) states that a person's self-efficacy is comprised of combination of belief related to three questions: Am I capable of doing the things that are necessary for success, developing a plan that will lead to success, and persisting in my effort long enough to achieve success? Thus the results of the strength or toughness of selfefficacy can be expected of a person: whether repetition or modification of planned behavior, how much effort will be made, and how long one will survive in the face of obstacles and challenging experience.

\section{Mathematics Teacher Competency}

Teacher competence, on Law No. 14 Year 2005 of Republic of Indonesia about Teachers and Lecturers, article 32, states that the promotion and development of the teaching profession as referred to in paragraph (1) includes the pedagogical competence, personal competence, social competence, and spiritual competence. In relation to the competence of mathematics teachers, there are some opinions that highlight the mastery of substance, achievement in performing or teaching in the classroom, peers assessment, or preparation of the portfolio. Fennema and Franke (Turnuklu \& Yesildere, 2007, p. 2) mention that some of the components of mathematical knowledge to be possessed by a mathematics teacher: knowledge of mathematics, knowledge representation/math symbols, knowledge of the students, and knowledge about teaching and decision making.

Another opinion from Kulm and Wu (Turnuklu \& Yesildere, 2007, p. 3) mentions the beliefs on a reciprocal basis underlying the substance of pedagogical content knowledge. Pedagogical content knowledge comprises of three components: content knowledge, teaching practice, and knowledge of the curriculum, each of which interacts reciprocally. In the practice of teaching, a teacher must understand the thought of his/her students (knowing students' thinking). The understanding of students' thoughts is translated into five components namely: addressing students' misconception, engaging student learning in math, student learning, promoting student thinking in mathematics, and building on student math idea. Thus, this shows that the conviction of a mathematics teacher will be the basis for the substance of pedagogical knowledge, which will ultimately lead to active student activities, anticipate misconceptions, and build mathematical ideas.

\section{Mathematics Teacher Self-efficacy}

Related to teacher efficacy, several studies support the theory that the belief in one's ability is the best predictor for the behavior of the completion of a task (Bandura, 1996, 1997; Pajares, 1996, in Leder, Pehkonen, \& Torner, 2002, p. 216). Referring to Bandura's concept of self-efficacy as confidence in one's ability to organize and carry out a number of actions needed to generate the expected result, with the same understanding, Philippou and Christou (Leder et al., 2002, p. 217), mention that the teaching efficacy can be understood as a belief in the ability of teachers to organize and create effective learning environments. The activities and actions of teachers are more dependent on what they believe than on what they know, or the competence they rarely achieve. The same idea is said by Hoy and Spero (2005, p. 29) that teachers 'sense of efficacy as teachers' judgments about reviews their capabilities to promote student learning.

Gibson and Debo (Leder et al., 2002, p. 218) classify the teacher's self-efficacy into two factors: general teaching efficacy (GTE) and personal teaching efficacy (PTE). GTE refers to teachers' general feeling that their teaching and education system will be able to grow and develop students' academic achievement despite the negative influence of outside 
teachers. Meanwhile, personal teaching efficacy (PTE) is intended as a reflection of teachers conviction on their own to continue the significant learning and student achievement. Furthermore, Philippou and Christou (Leder et al., 2002, p. 217) state that the efficacy of belief about the teaching of mathematics is mostly, but not entirely, shaped by one's experience and knowledge of mathematics and its pedagogy. The process skills of mathematics teachers should also be developed, i.e skills in reasoning, understanding of the concept, the relationship between concepts, representation, communication, and problem solving.

In relation to teachers' efficacy and competence, Tschannen-Moran et al. (1998) proposed an Integrated Model of Teacher Efficacy Cyclical. Furthermore, with reference to Lee (2009, p. 15) about the teacher's selfconcept, as well as the opinion of Gibson and Dembo (1984) about the outcome efficacy, the approach develops a system model as presented in Figure 1.

\section{Method}

Research on the construct of the instrument for measuring junior high school mathematics teacher self-efficacy is a kind of developmental research (Borg \& Gall, 1983, p. $775)$, to obtain a construct of dimensions or factors in relation to the self-efficacy of mathematics teachers, especially junior high school mathematics teachers in the Special Region of Yogyakarta.

This study was conducted over four months from September to December 2013) in four districts, namely Sleman, Bantul, Kulonprogro, and Gunungkidul regencies, as well as in the municipality of Yogyakarta in the of Special Region of Yogyakarta.

\section{Research Design}

The development of a modified construct in this study adapted Borg \& Gall's model, which was simplified from 10 steps into 6 steps. The development of the modified construct is presented in Figure 2.

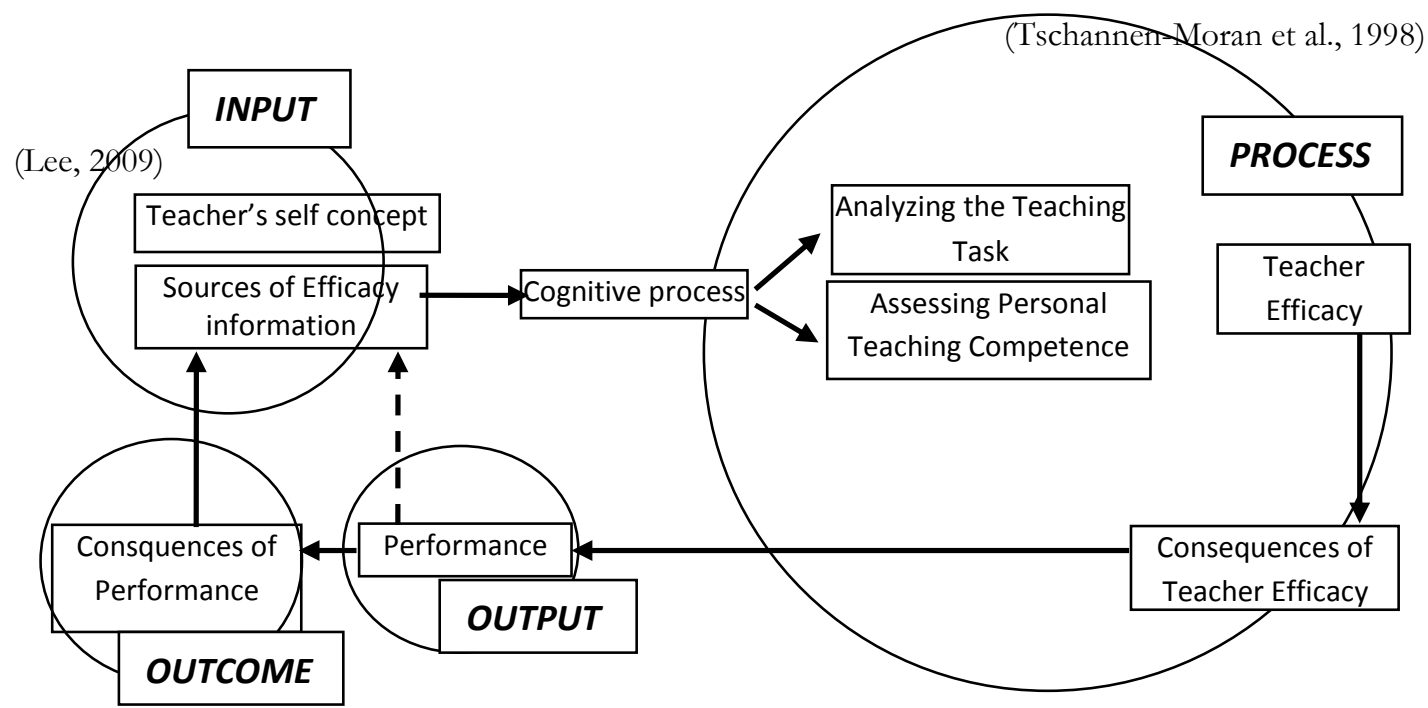

Gibson \& Dembo (1984) and

Soodak \& Podell (1996)

Figure 1. Development of "The cyclical nature of teacher eficacy" (Tschannen-Moran et al., 1998); "Outcome efficacy" (Gibson \& Dembo, 1984; Soodak \& Podell, 1996), through the system approach. 


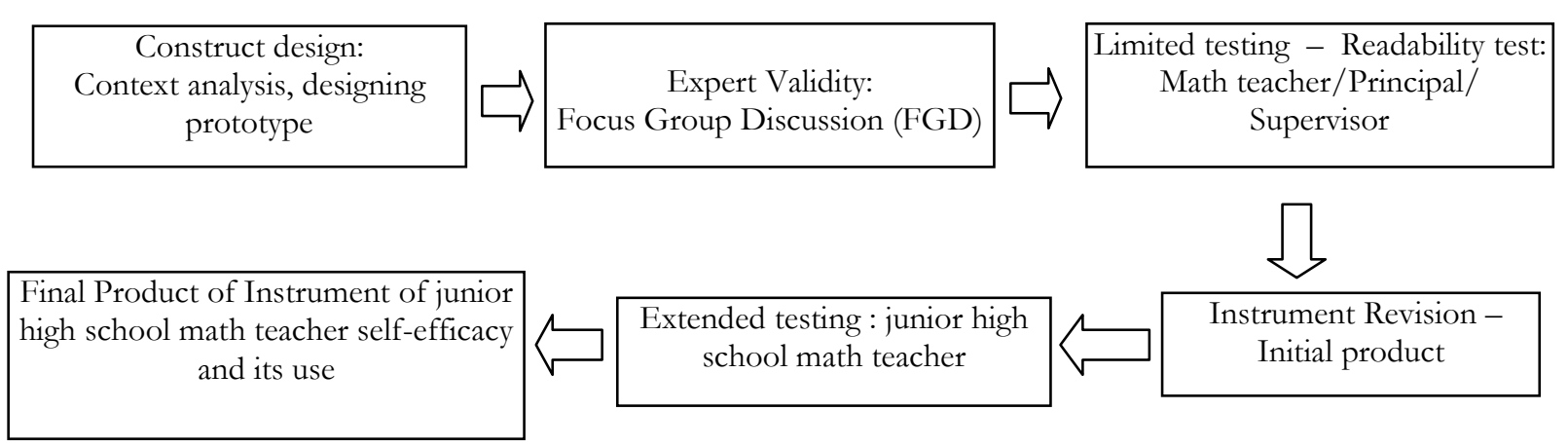

Figure 2. Research design on the development of the instrument of junior high school mathematics teacher self-efficacy

There are six stages in this research design. First, a construct was designed. This activity consisted of context analysis, relevant literature review, and prototype designing. At this stage, a preliminary instrument of mathematics teacher efficacy was developed. It consisted of four dimensions, namely: Personal Efficacy (PE), General Teaching Efficacy (GTE), Subject-Matter Teaching Efficacy (STE), and Outcome Efficacy (OE) based on the relevant theory and literature. The total number of items in this prototype instrument was 94 items consiting of: PE (25 items), GTE (26 items), STE (33 items), and OE (10 items). Likert scale was used with the rating scale of $1-4$.

The second stage was validation by experts. This activity was a focus group discussion (FGD) involving eight experts or specialists from universities, consisting of: two mathematics education experts, three psychometric experts, one educational psychologist, and two experts on teacher training. The aspects assessed included: blue-print and indicators, clarity of the instruments, and the model development. The FGD results obtained content validity (content validity coefficient) through Aiken validity (Aiken, 1985, p. 132; Azwar, 2013, p. 134) was 0.71, meaning that the instrument could be used for collecting data.

The third stage was the limited testing. This activity involved 32 people, consisting of 22 mathematics teachers (of three districts in the province) and seven principals and three supervisors. The results of this readability test obtained a score of 4.13 which means that the instrument could be used.
The fourth stage was the revision or improvement. Based on the expert judgement in FGD and the limited testing, revision was done to improve the instrument in accordance with the input and advice from the experts. The fifth stage was the extended testing. In this case the test subjects were as many as 274 mathematics teachers in the Special Region of Yogyakarta.

The sixth stage was the final product and its use. The data from the extended testing were analyzed by using Lisrel 8.80 through the the first order and the second order analysis of CFA in order to obtain a suitable construct between the model and data. Based on this instrument, the researchers employed it for mapping the level of mathematics teacher self-efficacy.

\section{Population and Sample}

The population of this research was junior high school mathematics teachers, by referring to the data of the Provincial Education Department of Yogyakarta in 2012. It consisted of 816 junior high school mathematics teachers. Using the proportionate random sampling technique (Cohran, 2010, p. 85) the researcher established a sample of 274 teachers, consisting of 38 teachers from Yogyakarta City, 85 from Sleman, 70 from Bantul, 38 from Kulonprogro, and 43 from Gunungkidul. The sample size in the CFA analysis was determined by the number of the observed variables or items. According to Hair, Black, Babin, and Anderson (2006), for the sample size, it is recommended to use the estimates of the Maximum Likelihood (ML) at 100-200. 
Data Analysis Technique

In data analysis, Confirmatory Factor Analysis (CFA) consisting of first-order and second order with the software of Lisrel 8.80 was used. The evaluation criteria for the model fit were by $\mathrm{p}$-value on Chi-square $(\chi 2)$ and the Root Mean Square Error of Approximation (RMSEA). The model was declared fit if the $\mathrm{p}$-value was greater than Chi-square $(\chi 2)$; was not significant if $\mathrm{p}$-value $>0.05$, meaning there is no significant difference between the model with the data Joreskog \& Sorbom, 2003, p. 128). The evaluation model with the RMSEA was expected to show the RMSEA value of $\leq 0.05$ for the model considered as close to or the RMSEA value of $\leq 0.08$ for a model declared as a good fit model. Furthermore, the fit instrument construct was used to map the level of mathematics teacher selfefficacy, referring to the score of Mathematics Teacher Self-efficacy (X): X $<\mu-1 \sigma$ (low category), $\mu-1 \sigma \leq<\mu \mathrm{X}+1 \sigma$ (medium category), and $\mu+1 \sigma \leq \mathrm{X}$ (high category).

\section{Findings and Discussion}

The First Order Analyisis

\section{Dimension of Personal Efficacy (PE)}

This dimension consists of three indicators: mathematics self-concept, math anxiety and internalizing the source of efficacy. PE consisted of 25 items, the number of the items might decrease gradually in the the first order analysis for obtaining a fit model. Items V2, V5, V6, V7, V9, and V10 were eliminated because the t-value of the loading factor < 1.96. Items V24 and V25 were also eliminated because of a negative loading factor value. Items V3, V13, V18, V19, V20 and V23 errors were eliminated because they shared a variance among items as the cause of the goodness of fit value was not a significant dimensional construct.

The result of the first order analysis of CFA showed that the model was fit to the data by obtaining the Chi-Square $=53.61 \mathrm{df}$ $=44 \mathrm{p}$-value $=0.15201$ and RMSEA $=0.020$. The number of items decreased from 25 items into 11 items, with the loading factor of 0.19 to 0.64 . So the items on the dimensions of $\mathrm{PE}$ were 11 items, namely items V1, V4, V8, V11, V12, V14, V15, V16, V17, V21, and V22.

\section{Dimension of General Teaching Efficacy}

This dimension consited of four indicators: pedagogy content knowledge, classroom management, student engagement, and parental involvement. GTE consisted of 26 items, the number of item might decrease gradually in the first order analysis for obtaining a fit model. Items V29 and V30 were eliminated because the t-value of the loading factor $<1.96$. Items V26 and V43 were also eliminated because it had an error value variance greater than the value of the loading factor which caused the goodness of fit value was not significant.

The result of the first order analysis of CFA showed that the model was fit to the data by obtaining Chi-Square $=66.59$; $\mathrm{df}=$ 54 , $\mathrm{p}$-value $=0.11670$ and RMSEA $=0.029$. The number of the items decreased from 26 items into 12 items with the loading factor of 0.22 to 0.71 . Thus, the number of the fit items in dimensions of GTE was 12 items, namely items V28, V31, V35, V38, V41, V44, V45, V47, V48, V49, V50, dan V51.

\section{Dimension of Subject-matter Teaching Efficacy (STE)}

This dimension consisted of three indicators: knowledge of junior high school mathematics content, teaching strategies, and fostering student mathematical power. STE consisted of 33 items, the number of items might decrease gradually in the first order analysis for obtaining a fit model. Items V52, V56, V57, V58, V66, and V67 were eliminated because the value of $t$ loading factor $<1.96$. The items that were removed were Items V53, V54, V59, V60, V61, V62, V65, V68, V69, V70, V71, V74, and V78 because the error of variance was much greater than the value of the factor loading, causing the value of goodness of fit not significant.

The result of the first order analysis of CFA showed that the model was fit to the data by obtaining Chi-Square $=24.49$; $\mathrm{df}=$ 20; $\mathrm{p}$-value $=0.2216$, RMSEA $=0.029$. The number of the items decreased from 33 items 
into 13 items with the loading factor from 0.22 to 0.40 . Thus, there were 13 items left in STE's dimensional. They were items V55, V63, V72, V73, V75, V76, V77, V79, V80, V81, V82, V83, and V84.

\section{Dimension of Outcome Efficacy (OE)}

The dimension of Outcome Efficacy $(\mathrm{OE})$ consisted of three indicators, namely: student achievement, building mathematics attitude, and the continouing study. OE consisted of 10 items, and the number might decrease gradually in the first order analysis for obtaining a fit model. All items had a t-value of loading factor $>1.96$ and no negative loading factor value. However, items V86 and V91 were eliminated because they had a value of error variance much greater than the value of the loading factor, causing the value of goodness of fit not significant.

The result of the first order analysis of CFA showed that the model was fit to the data by obtainng Chi-Square $=14.60 ; \mathrm{df}=9$; p-value $=0.10256 ;$ RMSEA $=0.048$. The number of the items decreased from 10 items to eight items, with the loading factor from 0.32 to 0.42 . Therefore, the number of items was reduced to 8 items, namely V85, V87, V88, V89, V90, V92, V93 and V94.

\section{The Second Order Analysis}

Based on the items obtained in each dimension in the first order analysis, the second order analysis of CFA was done. Several simulations and iterations among these dimensions were done for obataining a fit model, such as: PE and GTE; STE and OE; dimensions of PE, GTE, and dimension STE. Finally, iterations of the next dimensions of $\mathrm{PE}$, GTE, STE, and OE, derived a construct model that was fit to the data, as presented in Figure 3.

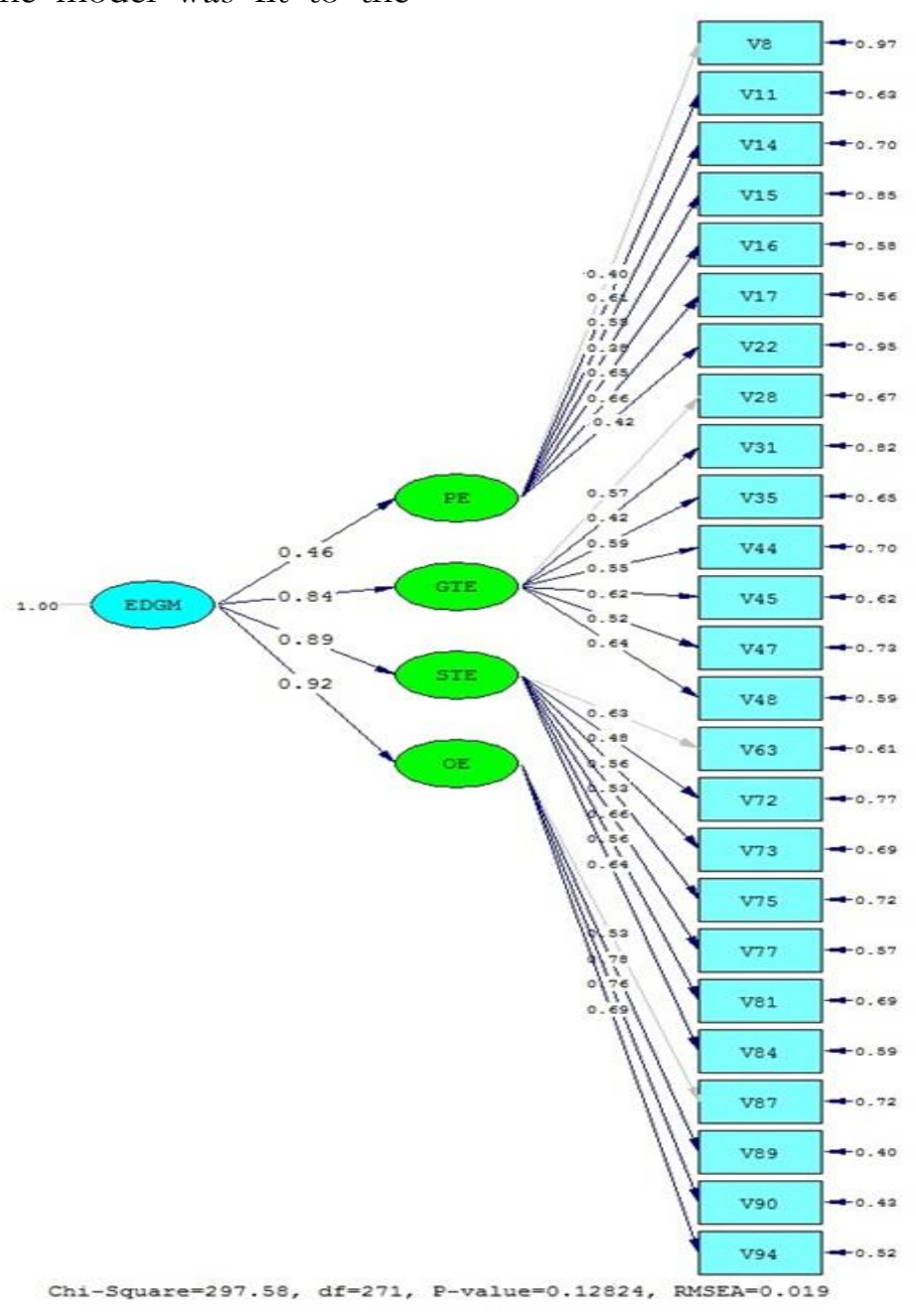

Figure 3. Path diagram of the second order analysis output 
Table 1. Results of the second order CFA of the instrument of junior mathematics teachers' selfefficacy with 25 items

\begin{tabular}{|c|c|c|c|c|}
\hline Item & Loading Factor & $t$-value & $R^{2}$ & Result \\
\hline \multicolumn{5}{|l|}{ Dimension: $P E$} \\
\hline Item 8 & 0.40 & --- & 0.19 & Reference Item \\
\hline Item 11 & 0.61 & 2.68 & 0.37 & Item Fit \\
\hline Item 14 & 0.58 & 2.62 & 0.30 & Item Fit \\
\hline Item 15 & 0.48 & 2.47 & 0.25 & Item Fit \\
\hline Item 16 & 0.65 & 2.63 & 0.42 & Item Fit \\
\hline Item 17 & 0.66 & 2.67 & 0.44 & Item Fit \\
\hline Item 22 & 0.42 & 2.53 & 0.21 & Item Fit \\
\hline \multicolumn{5}{|l|}{ Dimension: $G T E$} \\
\hline Item 28 & 0.57 & --- & 0.33 & Reference Item \\
\hline Item 31 & 0.42 & 6.41 & 0.18 & Item Fit \\
\hline Item 35 & 0.59 & 7.20 & 0.35 & Item Fit \\
\hline Item 44 & 0.55 & 6.05 & 0.30 & Item Fit \\
\hline Item 45 & 0.62 & 6.70 & 0.38 & Item Fit \\
\hline Item 47 & 0.52 & 5.48 & 0.27 & Item Fit \\
\hline Item 48 & 0.64 & 7.65 & 0.41 & Item Fit \\
\hline \multicolumn{5}{|l|}{ Dimension: $S T E$} \\
\hline Item 63 & 0.62 & -- & 0.39 & Reference Item \\
\hline Item 72 & 0.48 & 6.04 & 0.23 & Item Fit \\
\hline Item 73 & 0.56 & 8.11 & 0.31 & Item Fit \\
\hline Item 75 & 0.52 & 7.68 & 0.28 & Item Fit \\
\hline Item 77 & 0.66 & 8.71 & 0.43 & Item Fit \\
\hline Item 81 & 0.56 & 8.35 & 0.31 & Item Fit \\
\hline Item 84 & 0.64 & 8.42 & 0.41 & Item Fit \\
\hline \multicolumn{5}{|l|}{ Dimension: $O E$} \\
\hline Item 87 & 0.52 & -- & 0.28 & Reference Item \\
\hline Item 89 & 0.78 & 8.17 & 0.60 & Item Fit \\
\hline Item 90 & 0.76 & 8.00 & 0.57 & Item Fit \\
\hline Item 94 & 0.69 & 7.31 & 0.48 & Item Fit \\
\hline
\end{tabular}

The results of the tests performed on the measurement model of the second order analysis of CFA on 54 items resulted in $\mathrm{p}$ value $=0.12824(\mathrm{p}>0.05)$ and RMSEA $=$ 0.019 (RMSEA <0.05). Based on the data, pvalue and RMSEA were successfully met so that it could be concluded this model was really fit with the data. The RMSEA value of 0.019 indicates that the model is very fit. In other words, all 25 items are valid indicators for measuring the instrument construct of self-efficacy of junior high school mathematics teachers. These results also showed that 25 items measured a latent variable, which was the self-efficacy of mathematics teachers. It was concluded that self-efficacy measurement instrument for mathematics teachers met unidimensionality assumptions. Table 1 is the table of all fit items of the results of second order CFA for measuring of junior high school mathematics teacher self-efficacy.

Based on the t-value of the second order CFA testing, it was known that all of the items were fit to measure junior high school mathematics teacher self-efficacy because the whole t-value was greater than 1.96. From Table 1, it is also noted that Item 89 has the highest contribution to the measuring instrument with the loading factor of 0.78 , while Item 15 gives the smallest contribution to the loading fator of 0.38 .

Mapping of Mathematics Teacher Self-Efficacy

The degree or level of mathematics teacher self-efficacy was obtained from the interpretation of the scores of an individual mathematics teacher as many as 274 teachers within 25 fit items. The scores obtained in the questionaire are raw scores, which need to be converted first into $z$-standard score, with $\mu=$ 0 , and $\sigma=1$. However, because the standard $z$-scores allow their negative score, then for the ease of readability and interpretation, they need to be converted into t-score, with $\mu=$ 
50 , and $\sigma=10$. The result of the conversion of the scoring through a simple program MS Excel, and which referred to the categorization, as presented in the data analysis, shows the obtained mapping of mathematics teacher self-efficacy for each diemnsion as in Table 2. Meanwhile, the percentage of respondents' MTSE level is shown in Figure 4.

\section{Discussion}

The results of the analysis of the second order with Chi-Square $=297.58$; df $=271$; value $=0.12824 ;$ RMSEA $=0.019 ; 25$ out of 54 items are with the factor loading $(\lambda)$ of each dimension PE, GTE, STE, and OE consecutively being $0.46 ; 0.84 ; 0.89$ and 0.92 . Thus it can be said that the model was fit to the data.

\section{Dimension of Personal Efficacy (PE)}

The dimension of Personal Efficacy contains three indicators, from the initial 11 items (the first order) it decreases to 7 items (the second order). Those three indicators include (a) mathematics self-concept, with item descriptors: efficacy of the ability to provide necessary information known to the students in learning mathematics (V8); (b) mathematics anxiety, item descriptors; efficacy on the readiness of the teachers when they would teach mathematics (V11), tranquility or comfort during mathematics learning (V14), the level of concern toward the material that was not be acquired (V15), having difficulty in concentrating while teaching mathematics (V16), and concerns if there were other people observing their teaching (V17); (c) the internalization of the source of efficacy, with efficacy item descriptor against social persuasion such as: invitations, suggestions, and verbal advice from a colleague which can push them to perform task (V22).

Table 2. Frequency recapitulation of mathematics teacher self-efficacy (MTSE) level for each dimension

\begin{tabular}{|c|c|c|c|c|c|}
\hline \multirow[b]{2}{*}{ Category } & \multicolumn{4}{|c|}{ Dimensions/Factors } & \multirow[b]{2}{*}{ MTSE } \\
\hline & PE & GTE & STE & OE & \\
\hline Low $(\mathrm{L})$ & 82 & 94 & 94 & 93 & 93 \\
\hline Medium (M) & 192 & 179 & 181 & 170 & 178 \\
\hline $\operatorname{High}(\mathrm{H})$ & 0 & 2 & 4 & 1 & 4 \\
\hline \multicolumn{5}{|c|}{ Total Number } & 274 \\
\hline
\end{tabular}

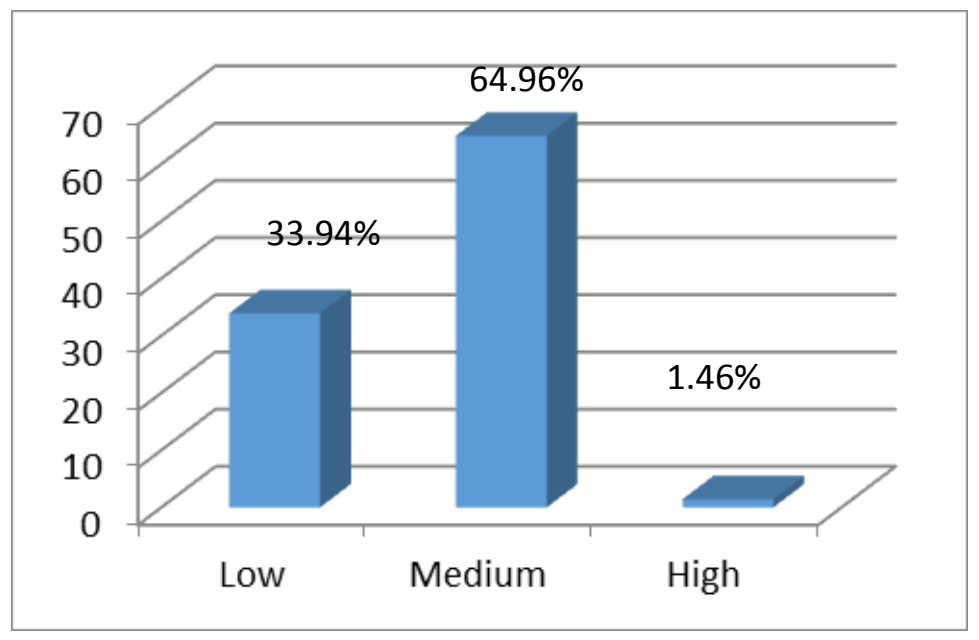

Figure 4. Graphic of Percentage MTSE level 
Dimension of General Teaching Efficacy (GTE)

General Teaching Efficacy dimension contains four indicators (from the initial $12 \mathrm{i}$ tems (the first order) decreasing to 7 items (the second order)). Those four indicators are: (a) pedagogy content knowledge of mathematics, with item descriptors including efficacy of ability to apply appropriate learning strategies in classroom practice (V28); (b) classroom management, with item descriptor efficacy toward abilities including students' drive to obey the rules in class (V31), explanation of the steps that must be performed by students in learning inside and outside the classroom (V35); (c) students' engagement with descriptor item efficacy toward abilities which help students to be actively involved in fun and meaningful learning (V44), maintain or restore the students' attention to stay focused on the material presented (V45), enhance students' understanding (V47) and assure the students that they can perform for completing the lesson task at school well (V48).

In GTE dimensions, there actually exist one more indicator, that is promoting the parental involvement in helping their children learning mathematics. At the time of the firstorder analysis of GTE, all of the three items representing this indicator exist, but unfortunately on the second order CFA three items are forced to be eliminated to fit its models. In this study, the respondents might argue that the indicators were not required to measure mathematics teacher self-efficacy. Thus, in other words, the respondents believed that parental involvement might not help their children learning. The existence of out-ofschool learning guidance, additional lesson, or private lesson would replace this role.

\section{Dimensions of Subject-matter Teaching Efficacy (STE)}

The dimensions of STE (Subject-matter Teaching Efficacy) consist of three indicators. The initial 13 items (the first order) decreased to 7 items (the second order). Those three indicators are: (a) the strategy of mathematics teaching, with item descriptors being the efficacy toward the ability to guide students in using a representation of an image, and symbol for mathematics learning (V63); (b) fostering students' mathematical power, with item descriptors being the efficacy in abilities to capture gaps between students' capability and competencies expected (V72), guiding students in examining the true relationship between one statement and others (V73), guiding students in developing a conjecture from available premises (V75), designing learning that encourages students to appreciate the benefits of mathematics (V77), managing the provision of questions to students (V81), and efficacy toward the ability to provide questions to students relating the idea of mathematics and its applications (V84).

In fact, there is one more indicator in STE dimension, that is acquiring mathematics content knowledge. At the time of firstorder analysis of GTE, there is one out of five items as a representation of this indicator, but in the second order CFA, one item was forced to be eliminated to fit its models. It means that in this study, these indicators were not required to measure mathematics teachers' self-efficacy. In other words, acquiring the mathematics content knowledge only by asking thorugh questionaire is not enough. Using a test to measure this domain is more reasonable. The existence of Teacher Competency Testing would support the absence of this indicator.

\section{Dimension of Outcome Efficacy (OE)}

The dimension of Outcome Efficacy (OE) consists of three indicators, the initial eight items (the first order) decrease to four items (the second order). Those three indicators include: (a) student achievement, with item descriptor efficacy against the ability to: guide students to succeed in the mathematics contest or mathematics olympiad in district region (V87), (b) bulid a mathematics attitudes, with items descriptor belief that mathematics learning done by the teacher is to promote students' critical logical thinking and to be consistent (V89), efficacy toward the belief that learning is done to guide the students to be honest, disciplined and responsible (V90), (c) continouing study, with item descriptor efficacy toward the belief that learning is done to be able to equip students to practice problem solving in their future life (V94). 
Based on the discussion, a framework of a construct for junior high school mathematics teacher self-efficacy in the Special Region of Yogyakarta could be made, consisting of four dimensions. The first dimension is Personal Efficacy (PE) with a loading factor $(\lambda=0.41)$, consisting of indicators including mathematics self-concept, mathematics anxiety, and also internalization source of efficacy. The second dimension is General Teaching Efficacy (GTE) with a loading factor $(\lambda=$ 0.84 ), consisting of indicators including pedagogy content knowledge, classroom management, and student engagement. The third dimension is Subject-matter Teaching Efficacy (STE) with a loading factor $(\lambda=0.89)$, consisting of indicators including teaching strategies and fostering students' mathematical power. The fourth dimension is Outcome Efficacy (OE) with a loading factor $(\lambda=0.92)$, consisting of indicators including student achievement, building mathematics attitude, and continuing study.
Mapping of Mathematics Teacher Self-Efficacy

Figure 4 shows that the percentage of mathematics teacher self-efficacy is $1.46 \%$ in a high category, $64.96 \%$ in a medium category, and $33.94 \%$ in a low category. With the hope of an ideal efficacy of mathematics teachers reaching high categories, as many as $98.54 \%$ of mathematics teachers should be enhanced for high category efficacy.

In order to give an idea of the profile of mathematics teacher self-efficacy in these categories and to make it easier to follow up the results of measurements of efficacy in the process of continuing professional development of mathematics teachers, and refer to the indicators and items of MTSE which have been fit and significant, Table 3 is a general description of MTSE (Mathematics Teacher Self-Efficacy) profile.

Table 3. General description of mathematics teacher self-efficacy

\begin{tabular}{|c|c|}
\hline MTSE Category & Description of MTSE \\
\hline $\begin{array}{l}\text { Low } \\
\text { (Score: } 24.96-49.92)\end{array}$ & $\begin{array}{l}\text { a. Not sure: the importance of understanding and the role of mathematics self- } \\
\text { concept, overcoming math anxiety, and internalization of the sources of self- } \\
\text { efficacy, in carrying out the task of teaching responsibility. } \\
\text { b. Not sure: able to master knowledge of the pedagogical substance, class-room } \\
\text { management, and students engagement } \\
\text { c. Not sure: able to perform mathematical learning strategies and fostering } \\
\text { students' mathematical power. } \\
\text { d. Not sure: able to improve student achievement, students' mathematical } \\
\text { attitudes, as well as provisions for the continuation of the study at the next level. }\end{array}$ \\
\hline $\begin{array}{l}\text { Medium } \\
\text { (Score: } 49.93-74.88 \text { ) }\end{array}$ & $\begin{array}{l}\text { a. Sure: the importance of understanding and the role of mathematics self- } \\
\text { concept, overcoming math anxiety, and internalization of the sources of self- } \\
\text { efficacy, in carrying out the task of teaching responsibility. } \\
\text { b. Sure: able to master knowledge of the pedagogical substance, classroom } \\
\text { management, and students engagement } \\
\text { c. Sure: able to perform mathematical learning strategies and fostering stu-dents' } \\
\text { mathematical power. } \\
\text { d. Sure: able to improve student achievement, students' mathematical atti-tudes, } \\
\text { as well as provisions for the continuation of the study at the next level. }\end{array}$ \\
\hline $\begin{array}{l}\text { High } \\
\text { (Score: } 74.89-100.00)\end{array}$ & $\begin{array}{l}\text { a. Very Sure: the importance of understanding and the role of mathema-tics self- } \\
\text { concept, overcoming math anxiety, and internalization of the sources of self- } \\
\text { efficacy, in carrying out the task of teaching responsibility. } \\
\text { b.Very Sure: able to master knowledge of the pedagogial substance, class-room } \\
\text { management, and students engagement } \\
\text { c. Very Sure: able to perform mathematical learning strategies and foster-ing } \\
\text { students' mathematical power. } \\
\text { d. Very Sure: able to improve student achievement, students' mathematical } \\
\text { attitudes, as well as provisions for the continuation of the study at the next level. }\end{array}$ \\
\hline
\end{tabular}




\section{Conclusion and Suggestions}

Based on the findings, some conclusions are drawn. First, the results in the second order analysis of the construct of the instrument for measuring the self-efficacy of junior high school mathematics teachers in the Special Region of Yogyakarta shows the model is fit to the data, indicated by Chi-Square $=297.58 ; \mathrm{df}=271 ; \mathrm{p}$-value $=0.12824$; RMSEA $=0.019$, from 54 items, 25 items obtained with factor loading $(\lambda)$ each dimension PE, GTE, STE, and OE consecutively are: $0.46 ; 0.84 ; 0.89$ and 0.92 .

The construct of the instrument for measuring self-efficacy of junior high school mathematics teachers in the Special Region of Yogyakarta consists of four dimensions. First, the dimensions of Personal Efficacy (PE) with a loading factor $(\lambda=0.41)$ with indicators: mathematics self concept, mathematics anxiety, and the internalization source of efficacy. Second, the dimensions of General Teaching Efficacy (GTE) with a loading factor $(\lambda=$ $0.84)$ with indicators: pedagogy content knowledge, classroom management and students engagement. Third, the dimensions of Subject-matter Teaching Efficacy (STE) with a loading factor $(\lambda=0.89)$ consisting of indicators: teaching strategies and fostering students' mathematical power. Fourth, Outcome Efficacy (OE) dimension with a loading factor $(\lambda=0.92)$, with indicators: student achievement, building mathematics attitude, and the continouing study.

The results of the mapping of the selfefficacy of mathematics teachers in the Special Region of Yogyakarta show that $43.07 \%$ of the teachers are categorized as low, $55.47 \%$ are categorized as moderate, and $1.46 \%$ are in high category.

Besides, some suggestions are proposed. First, further research or advanced analysis needs to determine the relationship between mathematics teacher self-efficacy and teacher performance. Second, research or further analysis is required to find out how instruments are constructed for senior or vocational high school mathematics teachers.

\section{References}

Aiken, L. R. (1985). Psychological testing and assessment (5th ed.). Boston, MA: Allyn and Bacon.

Azwar, S. (2013). Penyusunan skala psikologi (2nd ed.). Yogyakarta: Pustaka Pelajar.

Bandura, A. (1996). Self-efficacy in changing societies. New York, NY: Cambridge University Press.

Bandura, A. (1997). Self-efficacy: The exercise of control. New York, NY: W. H. Freeman and Company. Retrieved from https://books.google.co.id/books/abo ut/Self_Efficacy.html?id=eJ-PN9g_oEC\&redir_esc $=y$

Borg, W. R., \& Gall, M. D. (1983). Educational research: An introduction (4th ed.). New York, NY: Longman.

Burn, R. B. (1984). The self concept, theory, measurement, development, and behavior. New York, NY: Longman.

Cohran, W. G. (2010). Teknik penarikan sampel (Rusdiansya). New York, NY: John Wiley \& Sons.

Gibson, S., \& Dembo, M. H. (1984). Teacher efficacy: A construct validation. Journal of Educational Psychology, 76(4), 569-582. https://doi.org/10.1037/00220663.76.4.569

Hair, J. F., Black, W. C., Babin, B. J., \& Anderson, R. E. (2006). Multivariate data analysis. Upper Saddle River, NJ: Prentice-Hall.

Hastuti, H., Sulaksono, B., Akhmadi, A., Syukri, M., Sabainingrum, U., Ruhamaniyati, R., ... Suryahadi, A. (2009). Pelaksanaan sertifikasi guru dalam jabatan 2007: Studi kasus di Provinsi Jambi, Jawa Barat, dan Kalimantan Barat. Jakarta.

Hoy, A. W., \& Spero, R. B. (2005). Changes in teacher efficacy during the early years of teaching: A comparison of four measures. Teaching and Teacher Education, 21(4), 343-356. 
Jalal, F., Samani, M., Chang, M. C., Stevenson, R., Ragatz, A. B., \& Negara, S. D. (2009). Teacher certification in Indonesia: $A$ strategy for teacher quality improvement. Jakarta: Ministry of National Education.

Joreskog, K. G., \& Sorbom, D. (2003). Lisrel 8.54 belp file. Chicago, IL: Scientific Software International.

Kastberg, S. E., D'Ambrosio, B., McDermot, G., \& Saada, N. (2005). Context matters in assessing students' mathematical power. For the Learning of Mathematics, 25(2), 10-15.

Keller, J. M. (2010). Motivational design for learning and performance: The ARCS model approach. Florida: Springer.

Law No. 14 Year 2005 of Republic of Indonesia about Teachers and Lecturers (2005).

Leder, G. C., Pehkonen, E., \& Torner, G. (2002). Beliefs: A bidden variable in mathematics education. New York, NY: Kluwer Academic Publishers.

Lee, J. (2009). Self construct and anxiety across cultures. Princeton, NJ.

Leung, F., \& Ragatz, A. B. (2010). Inside Indonesia's classrooms: A TIMSS video study of teaching practices and student achievement. Jakarta: Human Development Department of East Asia and Pacific Region, World Bank Office.

Pajares, F. (1996). Self-efficacy beliefs in academic settings. Review of Educational Research, 66(4), 543-578.
PPPPTK Matematika. (2007). Laporan kegiatan Training need assessment (TNA) dan rekruitmen SMP tabun 2007. Yogyakarta.

Sadtyadi, H., \& Kartowagiran, B. (2014). Pengembangan instrumen penilaian kinerja guru sekolah dasar berbasis tugas pokok dan fungsi. Jurnal Penelitian Dan Evaluasi Pendidikan, 18(2), 290-304. https://doi.org/10.21831/pep.v18i2.28 67

Soodak, L. C., \& Podell, D. M. (1996). Teacher efficacy: Toward the understanding of a multi-faceted construct. Teaching and Teacher Education, 12(4), 401-411. https://doi.org/10.1016/0742051X(95)00047-N

Sumardyono. (2011). Kecemasan matematika guru matematika dinas pendidikan kota Banjarmasin. Edumat: Jurnal Edukasi Matematika, 2(4).

Tschannen-Moran, M., Hoy, A. W., \& Hoy, W. K. (1998). Teacher efficacy: Its meaning and measure. Review of Educational Research, 68(2), 202-248. https://doi.org/10.2307/1170754

Turnuklu, E. B., \& Yesildere, S. (2007). The pedagogical content knowledge in mathematics: Pre-service primary mathematics teachers' perspectives in Turkey. IUMPST: The Journal, 1(October). Retrieved from www.k12prep.math.ttu.edu 